Correspondence

Teresa A. Coutinho

teresa.coutinho@fabi.up.ac.za

\section{Pantoea allii sp. nov., isolated from onion plants and seed}

\author{
Carrie L. Brady, ${ }^{1}$ Teresa Goszczynska, ${ }^{2}$ Stephanus N. Venter, ${ }^{1}$ \\ Ilse Cleenwerck, ${ }^{3}$ Paul De Vos, ${ }^{3}$ Ronald D. Gitaitis ${ }^{4}$ \\ and Teresa A. Coutinho ${ }^{1}$
}
${ }^{1}$ Department of Microbiology and Plant Pathology, Forestry and Agricultural Biotechnology Institute (FABI), University of Pretoria, Pretoria 0002, South Africa
${ }^{2}$ Agricultural Research Council, Plant Protection Research Institute, Department of Microbiology and Plant Pathology, Private Bag X134, Queenswood 0121, Pretoria, South Africa
${ }^{3}$ BCCM/LMG Bacteria Collection, Ghent University, K.L. Ledeganckstraat 35, B-9000 Ghent, Belgium
${ }^{4}$ Department of Plant Pathology, Coastal Plain Experiment Station, University of Georgia, Tifton, GA 31793, USA

\begin{abstract}
Eight yellow-pigmented, Gram-negative, rod-shaped, oxidase-negative, motile, facultatively anaerobic bacteria were isolated from onion seed in South Africa and from an onion plant exhibiting centre rot symptoms in the USA. The isolates were assigned to the genus Pantoea on the basis of phenotypic and biochemical tests. 16S rRNA gene sequence analysis and multilocus sequence analysis (MLSA), based on $\operatorname{gr} B, r p o B$, infB and atpD sequences, confirmed the allocation of the isolates to the genus Pantoea. MLSA further indicated that the isolates represented a novel species, which was phylogenetically most closely related to Pantoea ananatis and Pantoea stewartii. Amplified fragment length polymorphism analysis also placed the isolates into a cluster separate from $P$. ananatis and $P$. stewartii. Compared with type strains of species of the genus Pantoea that showed $>97 \% 16 \mathrm{~S}$ rRNA gene sequence similarity with strain BD $390^{\top}$, the isolates exhibited 11-55\% whole-genome DNA-DNA relatedness, which confirmed the classification of the isolates in a novel species. The most useful phenotypic characteristics for the differentiation of the isolates from their closest phylogenetic neighbours are production of acid from amygdalin and utilization of adonitol and sorbitol. A novel species, Pantoea allii sp. nov., is proposed, with type strain BD $390^{\top}$ (=LMG $\left.24248^{\top}\right)$.
\end{abstract}

Diseases of onion that are caused by Pantoea ananatis (Gitaitis \& Gay, 1997) and Pantoea agglomerans (Edens et al., 2006; Hattingh \& Walters, 1981) are characterized by leaf blight, centre leaf rot, seed stalk necrosis and rot and bulb decay. These diseases can lead to significant economic losses (Hattingh \& Walters, 1981; Walcott et al., 2002). Centre rot of onion, induced by $P$. ananatis, has never been

Abbreviation: MLSA, multilocus sequence analysis.

The GenBank/EMBL/DDBJ accession number for the 16S rRNA gene sequence of strain $\mathrm{BD} 390^{\top}$ is AY530795 and those of the housekeeping gene sequences of strains $\mathrm{BD} 309, \mathrm{BD} 377, \mathrm{BD} 390^{\top}$, BD 380, BD 381, BD 383, BD 391 and BD 392 are EF988778, EF988782, EF988783, FJ409060-FJ409064 (gyrB), EF988950, EF988954, EF988955, GU458425-GU458429 (rрoB), EF988864, EF988868, EF988869, GU458420-GU458424 (infB) and EF988691, EF988695, EF988696, GU458415-GU458419 (atpD), respectively.

A supplementary figure and two supplementary tables are available with the online version of this paper. observed in South Africa, although the pathogen has been isolated from locally produced onion seed (Goszczynska et al., 2006). Members of the genus Pantoea isolated from onion in the USA and South Africa are typically identified as $P$. ananatis on the basis of only biochemical and physiological characteristics (Gitaitis \& Gay, 1997; Walcott et al., 2002) and 16S rRNA gene sequencing (Goszczynska et al., 2006). It has been noted that such methods are often insufficient for accurate species identification (Stackebrandt et al., 2002; Wayne et al., 1987), as is the case in the genus Pantoea (Brady et al., 2008, 2009, 2010a).

In 2004, several yellow-pigmented bacterial strains were isolated from onion seed in South Africa. These isolates were tentatively identified as members of the genus Pantoea by phenotypic testing. Pathogenicity tests with the isolates and strains isolated from diseased onion plants in the USA showed them all to be pathogenic to the two onion cultivars tested, causing leaf and stalk necrosis (Goszczynska et al., 
2006). Two representative strains from South Africa and one strain from the USA were included in a multilocus sequence analysis (MLSA) of the genus Pantoea based on partial sequences of four housekeeping genes, $g y r B, r p o B$, inf $B$ and atpD (Brady et al., 2008). MLSA placed the three isolates from onion (referred to as MLSA group G) in a separate and strongly supported cluster that was phylogenetically most closely related to $P$. ananatis and Pantoea stewartii and indicated that the isolates represented a novel species of the genus Pantoea. In the present study, these three isolates and five additional isolates from onion seed in South Africa were investigated.

\section{Strains}

A list of strains used in this study is presented in Supplementary Table S1 (available in IJSEM Online). The isolates from onion were maintained in milk-glycerol liquid medium at $-20{ }^{\circ} \mathrm{C}$ and recovered on nutrient agar by incubation at $25^{\circ} \mathrm{C}$ for $24 \mathrm{~h}$. Reference strains were recovered following instructions given by the BCCM culture collection.

\section{5 rRNA gene sequence analysis}

The almost-complete (1346 bp) 16S rRNA gene sequence was determined for strain $\mathrm{BD} 390^{\mathrm{T}}$ using the primers described by Weisburg et al. (1991) and sequencing conditions as described by Goszczynska et al. (2006). Sequences were aligned using CLUSTAL X (Thompson et al., 1997) and overhangs were trimmed. MODELTEST version 3.7 (Posada \& Crandall, 1998) was used to determine the bestfit evolutionary model. Maximum-likelihood and neighbour-joining analyses were performed using PhyML (Guindon \& Gascuel, 2003) and PAUP version 4.0b10 (Swofford, 2000), respectively, by applying the models and parameters determined by MODELTEST. Bootstrap analysis with 1000 replicates was performed to assess the reliability of the clusters.

In the maximum-likelihood phylogenetic tree based on 16S rRNA gene sequences (Fig. 1), strain BD $390^{\mathrm{T}}$ clustered with members of the genus Pantoea with high bootstrap support, but on a separate branch, which indicated that the isolate probably represented a novel Pantoea species. Furthermore, strain $\mathrm{BD} 390^{\mathrm{T}}$ had the eight 16S rRNA gene signature nucleotides that are specific for the genus Pantoea and that differentiate the genus from the closely related genus Tatumella (Brady et al., 2010a). Strain BD $390^{\mathrm{T}}$ showed $>97 \% 16 \mathrm{~S}$ rRNA gene sequence similarity to Pantoea agglomerans NCTC $9381^{\mathrm{T}}, P$. ananatis $\mathrm{LMG} 2665^{\mathrm{T}}, P$. anthophila LMG $2558^{\mathrm{T}}$, P. brenneri LMG $5343^{\mathrm{T}}$, P. calida $1400 / 07^{\mathrm{T}}$, P. conspicua LMG $24534^{\mathrm{T}}$, P. deleyi LMG $24200^{\mathrm{T}}$, P. dispersa LMG $2603^{\mathrm{T}}$, P. eucalypti LMG $24197^{\mathrm{T}}$, P. gaviniae A18/07 ${ }^{\mathrm{T}}$, P. septica LMG $5345^{\mathrm{T}}$, P. stewartii subsp. stewartii LMG $2715^{\mathrm{T}}$, P. stewartii subsp. indologenes LMG $2632^{\mathrm{T}}$ and P. vagans $\mathrm{LMG} 24199^{\mathrm{T}}$.

\section{gyrB, rpoB, infB and atpD sequence analysis}

Although strain $\mathrm{BD} 390^{\mathrm{T}}$ clustered closely with members of the genus Pantoea in the 16S rRNA gene phylogenetic tree with high support, this study also used partial sequences of housekeeping genes, which have been shown to be more reliable genetic markers for identification and phylogenetic analysis (Brady et al., 2008). MLSA based on partial gyrB, $r p o B$, infB and atpD sequences had been carried out previously on three of the isolates included in this study (Brady et al., 2008). In the present study, five additional isolates from onion seed were included in the MLSA scheme using the same primers and conditions. Sequence analysis and tree construction were performed on concatenated sequences as well as single gene sequences, as described above. Members of the closest phylogenetic relatives of the genus Pantoea, the genera Erwinia and Tatumella, were included in the analysis.

The eight isolates formed a distinct well-supported cluster that was closely related to $P$. ananatis and $P$. stewartii, not only in the phylogenetic tree based on the concatenated sequences (Fig. 2), but also in each of the single gene-based trees (not shown), which suggested that the isolates represented a novel species. The atpD sequences of the isolates were examined to determine whether they contained the signature nucleotides that can be used to characterize members of the genus Pantoea (Brady et al., 2010a); the isolates were found to include all 23 atpD signature nucleotides.

\section{Amplified fragment length polymorphism analysis}

Genomic DNA was extracted from six isolates using the GenElute Bacterial Genomic DNA kit (Sigma). Fluorescent amplified fragment polymorphism analysis was performed according to the method described previously (Brady et al., 2007). Band patterns were analysed with BioNumerics 5.0 (Applied Maths) and compared to a database containing profiles of reference strains of species of the genus Pantoea. An unweighted pair group method with averages dendrogram was constructed using Pearson's correlation (Supplementary Fig. S1). The isolates from onion formed a cluster separate from members of the genus Pantoea, with similarity values of $72-94 \%$, which suggested that the isolates belonged to a single novel species within the genus. The similarity values are in keeping with those observed previously for species of the genus Pantoea (Brady et al., 2007).

\section{DNA-DNA hybridization}

High-quality DNA for DNA-DNA hybridization was prepared by the method of Wilson (1987), with minor modifications (Cleenwerck et al., 2002). DNA-DNA hybridization was performed using the microplate method (Ezaki et al., 1989) with some modifications (Cleenwerck et al., 2002). The hybridization temperature was $45 \pm 1{ }^{\circ} \mathrm{C}$. Reciprocal reactions were performed for every hybridization pair and variation was within the limits of this method 


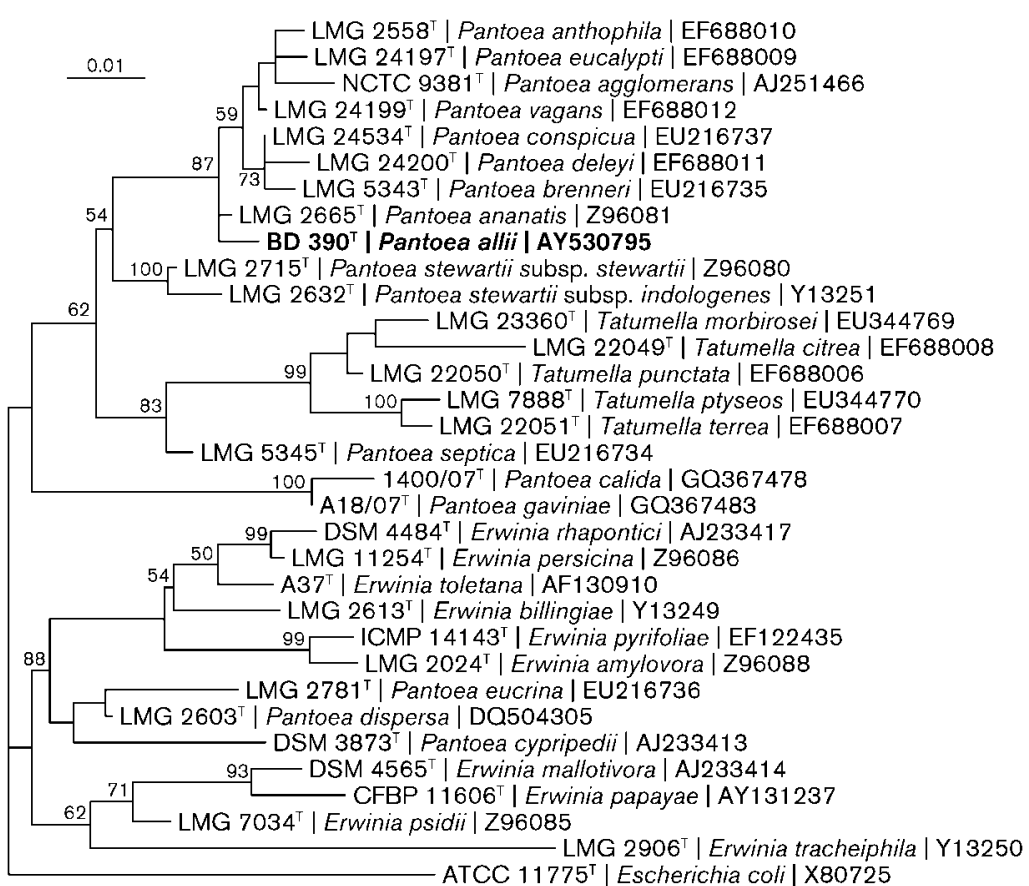

ATCC $11775^{\top} \mid$ Escherichia coli | X80725
Fig. 1. Maximum-likelihood tree based on almost-complete $16 \mathrm{~S}$ rRNA gene sequences showing the relationships of strain $B D 390^{\top}$ and type strains of species of the genera Pantoea, Erwinia and Tatumella. Bootstrap values $(>50 \%)$ based on 1000 replicates are shown at branch nodes. Escherichia coli ATCC $11775^{\top}$ was used as an outgroup. Bar, 0.01 substitutions per nucleotide position.

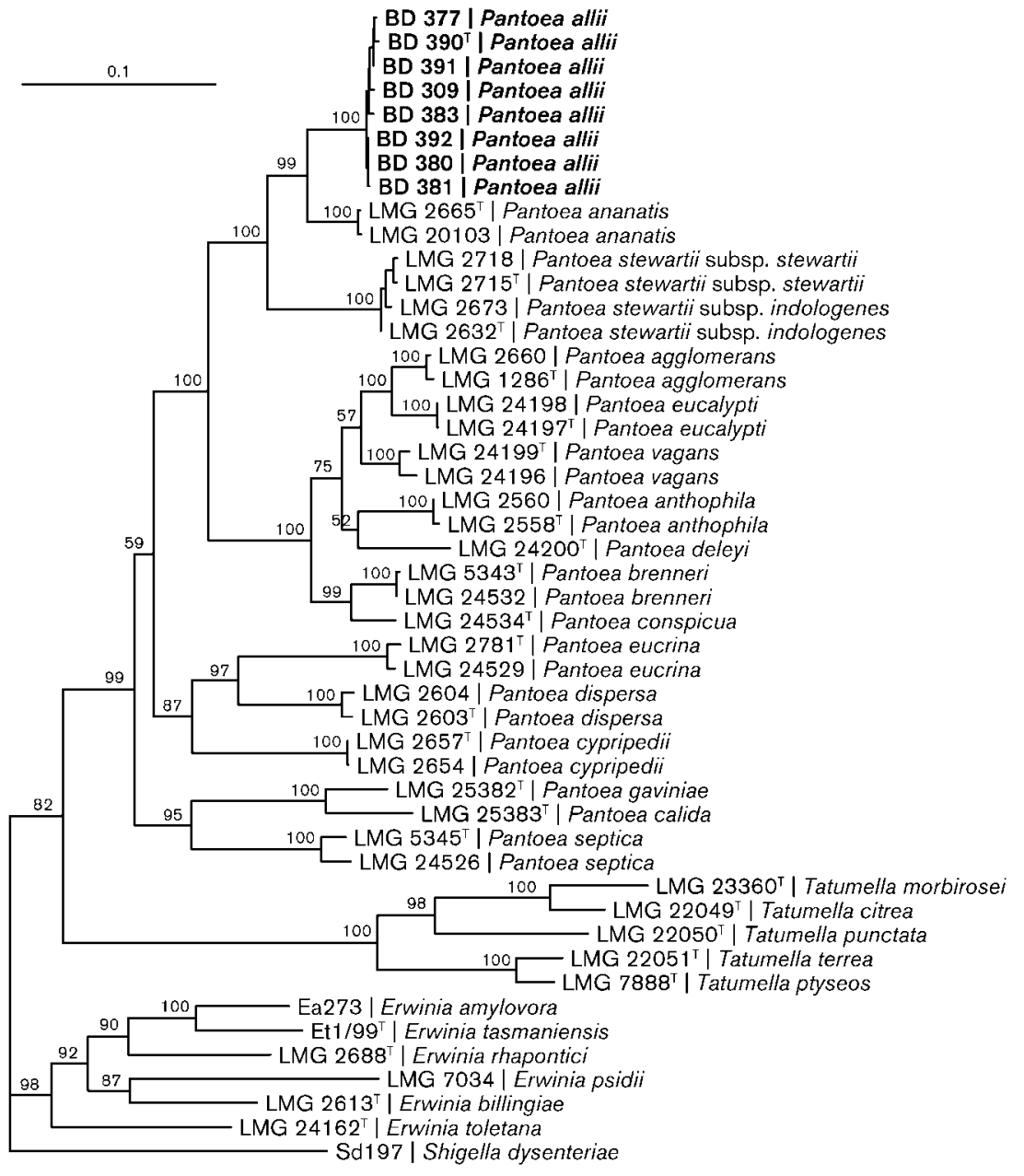

Fig. 2. Maximum-likelihood tree based on concatenated housekeeping gene sequences showing the relationships of members of strains of Pantoea allii sp. nov. and the genera Pantoea, Erwinia and Tatumella. Bootstrap values $(>50 \%)$ based on 1000 replicates are shown at branch nodes. Shigella dysenteriae Sd197 was used as an outgroup. Sequences for Erwinia amylovora Ea273, Erwinia tasmaniensis $\mathrm{Et} 1 / 99^{\top}$ and S. dysenteriae Sd197 were obtained from genome sequence databases (http://www.ncbi.nlm.nih. gov, http://www.sanger.ac.uk, http://asap.ahabs. wisc.edu/asap/home.php). Bar, 0.1 substitutions per nucleotide position. 
(Goris et al., 1998). The values presented are based on a minimum of four replicates (Supplementary Table S2). Three representative isolates from onion $\left(\mathrm{BD} 390^{\mathrm{T}}\right.$, BD 309 and BD 377) exhibited high levels of DNA-DNA relatedness to each other (90-99\%), which confirmed that they belonged to the same species. Strain $\mathrm{BD} 390^{\mathrm{T}}$ was tested against the members of the genus Pantoea with which it showed $>97 \% 16 \mathrm{~S}$ rRNA gene sequence similarity. The isolate displayed low levels of DNA-DNA relatedness (11$55 \%$ ) with these type strains. DNA-DNA relatedness between strain $\mathrm{BD} 390^{\mathrm{T}}$ and $P$. ananatis LMG $2665^{\mathrm{T}}$, its closest phylogenetic neighbour, was $55 \%$. The DNA-DNA hybridization data confirmed that the isolates from onion belonged to a single distinct genetic group within the genus Pantoea.

\section{DNA $\mathbf{G}+\mathbf{C}$ content}

The DNA G $+\mathrm{C}$ content, measured by HPLC (Mesbah et al., 1989), for the representative isolates $\mathrm{BD} 390^{\mathrm{T}}, \mathrm{BD}$ 309 and BD 377 was 53.6, 53.4 and $53.5 \mathrm{~mol} \%$, respectively. This is in keeping with the DNA G + C content of the genus Pantoea.

\section{Phenotypic tests}

Physiological and biochemical tests were performed on all of the isolates from onion and representative strains of the genus Pantoea using the API 20 E, API $50 \mathrm{CHB} / \mathrm{E}$ and Biotype-100 systems (bioMérieux), according to the manufacturer's instructions and conditions used for other novel Pantoea species (Brady et al., 2009, 2010a, b). Additional tests using GN2 MicroPlates (Biolog) were performed on strains $\mathrm{BD} 390^{\mathrm{T}}, \mathrm{BD} 309$ and $\mathrm{BD} 377$, according to the manufacturer's instructions. Cell suspensions for inoculation were prepared from cells prepared on tryptic soy agar for $12 \mathrm{~h}$ at $28{ }^{\circ} \mathrm{C}$. The API and Biolog tests were read after 24 and $48 \mathrm{~h}$ and the Biotype-100 tests were read each day for 6 days.

A good correlation between the Biotype-100 and Biolog GN2 results was observed, with consistent utilization of the major carbon sources by the strains tested. The results of the phenotypic characterization are presented in the species description. The isolates from onion were found to share all of the phenotypic traits that have been identified as characteristic of the genus Pantoea (Brady et al., 2010a). Furthermore, the isolates could be differentiated from their closest phylogenetic neighbours by their ability to produce acid from amygdalin and to utilize adonitol and sorbitol. The most useful phenotypic characteristics for the differentiation of the isolates from their closest phylogenetic neighbours are listed in Table 1.

In conclusion, the genotypic and phenotypic data presented in this study demonstrate that the strains isolated from onion represent a single novel species in the genus Pantoea. We therefore propose to classify the isolates in a novel species, for which the name Pantoea allii sp. nov. is proposed.
Table 1. Phenotypic characteristics that distinguish Pantoea allii sp. nov. from its closest phylogenetic neighbours

Species/subspecies: 1, Pantoea allii sp. nov. $(n=8) ; 2, P$. agglomerans $(n=3) ; 3$, P. ananatis $(n=4) ; 4$, P. anthophila $(n=2) ; 5$, P. brenneri $(n=1) ; 6$, P. conspicua $(n=1) ; 7$, P. deleyi $(n=1) ; 8$, P. eucalypti $(n=2)$; 9, $P$. stewartii subsp. stewartii $(n=1) ; 10, \quad P$. stewartii subsp. indologenes $(n=1) ; 11, P$. vagans $(n=7)$. Data for reference taxa were taken from Brady et al. (2009) and Grimont \& Grimont (2005) (columns 2, 3, 9 and 10), Brady et al. (2009) (columns 4, 7, 8 and 11) and Brady et al. (2010b) (columns 5 and 6). All data were generated under the same test conditions.,$+ 90-100 \%$ strains positive in 1-2 days; (+), 90-100\% strains positive in 1-4 days; d, 11-89\% strains positive in 1-4 days; (d), 11-89\% strains positive in 3-4 days; - , negative.

\begin{tabular}{|c|c|c|c|c|c|c|c|c|c|c|c|}
\hline Characteristic & 1 & 2 & 3 & 4 & 5 & 6 & 7 & 8 & 9 & 10 & 11 \\
\hline $\begin{array}{l}\text { Indole production } \\
\text { (API 20E) }\end{array}$ & + & - & + & - & - & - & - & - & - & + & - \\
\hline \multirow{2}{*}{\multicolumn{12}{|c|}{$\begin{array}{l}\text { Acid from (API } 50 \\
\text { CHB/E): }\end{array}$}} \\
\hline & & & & & & & & & & & \\
\hline Amygdalin & + & - & - & - & - & - & - & - & - & - & - \\
\hline D-Fucose & - & $\mathrm{d}$ & d & - & + & - & + & $\mathrm{d}$ & - & + & + \\
\hline Gentiobiose & + & + & d & - & - & - & + & - & - & + & - \\
\hline Glycerol & + & (d) & + & + & $\mathrm{d}$ & - & + & $\mathrm{d}$ & - & $\mathrm{d}$ & $\mathrm{d}$ \\
\hline \multicolumn{12}{|l|}{$\begin{array}{l}\text { Utilization of } \\
\text { (Biotype 100): }\end{array}$} \\
\hline Adonitol & + & - & - & - & - & - & - & - & - & - & - \\
\hline Gentiobiose & + & - & + & - & - & + & + & - & - & $\mathrm{d}$ & $\mathrm{d}$ \\
\hline Quinate & + & - & $(+)$ & $\mathrm{d}$ & - & - & - & - & - & + & - \\
\hline L-Rhamnose & + & + & d & + & + & + & + & + & + & $\mathrm{d}$ & + \\
\hline D-Sorbitol & + & - & d & - & - & - & - & - & - & - & - \\
\hline L-Tartrate & - & - & - & - & $\mathrm{d}$ & + & + & + & - & - & + \\
\hline
\end{tabular}

\section{Description of Pantoea allii sp. nov.}

Pantoea allii [al'li.i. N.L. n. Allium (from L. n. allium garlic) the scientific generic name of the onion (Allium sp.); N.L. gen. n. allii of/from Allium, referring to the isolation of the first strains from Allium cepa L.].

Cells are Gram-negative, short rods, non-capsulated, motile and non-spore-forming. Colonies are yellow, smooth, round and convex with entire margins on nutrient and tryptone glucose extract agar. Growth occurs at $30-40{ }^{\circ} \mathrm{C}$, but not at 4 or $44{ }^{\circ} \mathrm{C}$. Facultatively anaerobic. Oxidase-negative and catalase-positive. Lysine and ornithine are not decarboxylated. Produces $\beta$-galactosidase, indole and acetoin, but not urease, gelatinase or $\mathrm{H}_{2} \mathrm{~S}$. Utilizes citrate. Acid is produced from glycerol, L-arabinose, D-ribose, D-xylose, D-galactose, D-glucose, D-fructose, D-mannose, L-rhamnose, inositol, D-mannitol, D-sorbitol, $\mathrm{N}$-acetylglucosamine, amygdalin, arbutin, salicin, cellobiose, maltose, lactose, sucrose, trehalose, raffinose, gentiobiose and D-arabitol (API 50CHB/E). The following carbon sources are utilized at $30{ }^{\circ} \mathrm{C}$ : D-glucose, D-fructose, D-galactose, trehalose, D-mannose, melibiose, sucrose, raffinose, maltotriose, maltose, lactose, lactulose, $\alpha$ - and $\beta$-galactopyranoside, cellobiose, gentiobiose, 1-O-methyl $\beta$-D-glucopyranoside, aesculin, D-ribose, 
L-arabinose, D-xylose, L-rhamnose, D-arabitol, glycerol, myo-inositol, D-mannitol, D-sorbitol, adonitol, D-saccharate, mucate, meso-tartrate, D-malate, L-malate, cis-aconitate, trans-aconitate, citrate, D-glucuronate, D-galacturonate, 2- and 5-keto-D-gluconate, $N$-acetyl-D-glucosamine, D-gluconate, protocatechuate, quinate, DL-lactate, succinate, fumarate, DL-glycerate, D-glucosamine, L-aspartate, L-glutamate, L-proline, D- and L-alanine and L-serine (Biotype 100), dextrin, Tweens 40 and 80, pyruvic acid methyl ester, acetic acid, bromosuccinic acid, D- and L-alanine, L-asparagine, urocanic acid, thymidine, $\alpha$-D-glucose 1-phosphate and D-glucose 6-phosphate (Biolog GN). The following carbon substrates are not utilized at $30{ }^{\circ} \mathrm{C}$ : L-sorbose, palatinose, L-fucose, melezitose, L-arabitol, xylitol, dulcitol, D-tagatose, maltitol, turanose, hydroxyquinoline $\beta$-glucuronide, erythritol, L- and D-tartrate, tricarballylate, L-tryptophan, phenylacetate, 4-hydroxybenzoate, gentisate, 3-hydroxybenzoate, benzoate, 3-phenylpropionate, $\mathrm{m}$-coumarate, trigonelline, betaine, putrescine, 4-aminobutyrate, histamine, caprate, caprylate, L-histidine, glutarate, 5-aminovalerate, ethanolamine, tryptamine, itaconate, 3-hydroxybutyrate, propionate and L-tyrosine (Biotype 100), D-galactonic acid lactone, $\alpha$ - and $\beta$-hydroxybutyric acid, $\alpha$-ketobutyric acid, $\alpha$-ketoglutaric acid, $\alpha$-ketovaleric acid, malonic acid, sebacic acid, L-alaninamide, L-leucine, L-phenylalanine, D-serine, L-threonine, 2-aminoethanol and 2,3-butanediol (Biolog $\mathrm{GN})$. The DNA G $+\mathrm{C}$ content of the type strain is $53.6 \mathrm{~mol} \%$.

The type strain is $\mathrm{BD} 390^{\mathrm{T}}\left(=\mathrm{LMG} 24248^{\mathrm{T}}\right.$ ), isolated from onion seed in South Africa. Strains have been isolated from onion seed and onion plants exhibiting symptoms of leaf blight and bulb decay.

\section{Acknowledgements}

This study was supported by the South African-Flemish Bilateral Agreement, the Agricultural Research Council (ARC), the National Research Foundation (NRF) and the THRIP support programme of the Department of Trade and Industry, South Africa. The BCCM/ LMG Bacteria Collection is supported by the Federal Public Planning Service - Science Policy, Belgium. The authors thank Katrien Vandemeulebroecke for technical assistance.

\section{References}

Brady, C. L., Venter, S., Cleenwerck, I., Vancanneyt, M., Swings, J. \& Coutinho, T. (2007). A FAFLP system for the improved identification of plant-pathogenic and plant-associated species of the genus Pantoea. Syst Appl Microbiol 30, 413-417.

Brady, C. L., Cleenwerck, I., Venter, S. N., Vancanneyt, M., Swings, J. \& Coutinho, T. A. (2008). Phylogeny and identification of Pantoea species associated with plants, humans and the natural environment based on multilocus sequence analysis (MLSA). Syst Appl Microbiol 31, 447-460.

Brady, C. L., Venter, S. N., Cleenwerck, I., Engelbeen, K., Vancanneyt, M., Swings, J. \& Coutinho, T. A. (2009). Pantoea vagans sp. nov., Pantoea eucalypti sp. nov., Pantoea deleyi sp. nov. and Pantoea anthophila sp. nov. Int J Syst Evol Microbiol 59, 2339-2345.

Brady, C. L., Venter, S. N., Cleenwerck, I., Vandemeulebroecke, K., De Vos, P. \& Coutinho, T. A. (2010a). Transfer of Pantoea citrea,
Pantoea punctata and Pantoea terrea to the genus Tatumella emend. as Tatumella citrea comb. nov., Tatumella punctata comb. nov. and Tatumella terrea comb. nov. and description of Tatumella morbirosei sp. nov. Int J Syst Evol Microbiol 60, 484-494.

Brady, C. L., Cleenwerck, I., Venter, S. N., Engelbeen, K., De Vos, P. \& Coutinho, T. A. (2010b). Emended description of the genus Pantoea, description of four species from human clinical samples, Pantoea septica sp. nov., Pantoea eucrina sp. nov., Pantoea brenneri sp. nov. and Pantoea conspicua sp. nov., and transfer of Pectobacterium cypripedii (Hori 1911) Brenner et al. 1973 emend. Hauben et al. 1998 to the genus as Pantoea cypripedii comb. nov. Int J Syst Evol Microbiol 60, 2430-2440.

Cleenwerck, I., Vandemeulebroecke, K., Janssens, D. \& Swings, J. (2002). Re-examination of the genus Acetobacter, with descriptions of Acetobacter cerevisiae sp. nov. and Acetobacter malorum sp. nov. Int $J$ Syst Evol Microbiol 52, 1551-1558.

Edens, D. G., Gitaitis, R. D., Sanders, F. H. \& Nischwitz, C. (2006). First report of Pantoea agglomerans causing a leaf blight and bulb rot of onions in Georgia. Plant Dis 90, 1551.

Ezaki, T., Hashimoto, Y. \& Yabuuchi, E. (1989). Fluorometric deoxyribonucleic acid- deoxyribonucleic acid hybridization in microdilution wells as an alternative to membrane filter hybridization in which radioisotopes are used to determine genetic relatedness among bacterial strains. Int J Syst Bacteriol 39, 224-229.

Gitaitis, R. D. \& Gay, J. D. (1997). First report of a leaf blight, seed stalk rot, and bulb decay of onion by Pantoea ananas in Georgia. Plant Dis 81, 1096.

Goris, J., Suzuki, K., De Vos, P., Nakase, T. \& Kersters, K. (1998). Evaluation of a microplate DNA-DNA hybridization method compared with the initial renaturation method. Can J Microbiol 44, 1148-1153.

Goszczynska, T., Moloto, V. M., Venter, S. N. \& Coutinho, T. A. (2006). Isolation and identification of Pantoea ananatis from onion seed in South Africa. Seed Science Technol 34, 655-668.

Grimont, P. A. D. \& Grimont, F. (2005). Genus XXIII. Pantoea Gavini, Mergaert, Beji, Mielcarek, Izard, Kersters and De Ley 1989b, 343 ${ }^{\mathrm{VP}}$ emend. Mergaert, Verdonck and Kersters 1993, 171. In Bergey's Manual of Systematic Bacteriology, 2nd edn, vol. 2B, pp. 713-720. Edited by D. J. Brenner, N. R. Krieg, J. T. Staley \& G. M. Garrity. New York: Springer.

Guindon, S. \& Gascuel, O. (2003). A simple, fast, and accurate algorithm to estimate large phylogenies by maximum likelihood. Syst Biol 52, 696-704.

Hattingh, M. J. \& Walters, D. F. (1981). Stalk and leaf necrosis of onion caused by Erwinia herbicola. Plant Dis 65, 615-618.

Mesbah, M., Premachandran, U. \& Whitman, W. B. (1989). Precise measurement of the $\mathrm{G}+\mathrm{C}$ content of deoxyribonucleic acid by highperformance liquid chromatography. Int J Syst Bacteriol 39, 159-167.

Popp, A., Cleenwerck, I., Iversen, C., De Vos, P. \& Stephan, R. (2010). Pantoea gaviniae sp. nov. and Pantoea calida sp. nov., isolated from infant formula and an infant formula production environment. Int J Syst Evol Microbiol 60, 2786-2792.

Posada, D. \& Crandall, K. A. (1998). MODELTEST: testing the model of DNA substitution. Bioinformatics 14, 817-818.

Stackebrandt, E., Frederiksen, W., Garrity, G. M., Grimont, P. A. D., Kämpfer, P., Maiden, M. C. J., Nesme, X., Rosselló-Mora, R., Swings, J. \& other authors (2002). Report of the ad hoc committee for the re-evaluation of the species definition in bacteriology. Int J Syst Evol Microbiol 52, 1043-1047.

Swofford, D. L. (2000). PAUP*: Phylogenetic analysis using parsimony (and other methods), version 4. Sunderland, MA: Sinauer Associates. 
Thompson, J. D., Gibson, T. J., Plewniak, F., Jeanmougin, F. \& Higgins, D. G. (1997). The CLUSTAL_X windows interface: flexible strategies for multiple sequence alignment aided by quality analysis tools. Nucleic Acids Res 25, 4876-4882.

Walcott, R. R., Gitaitis, R. D., Castro, A. C., Sanders, F. H., Jr \& Diaz-Perez, J. C. (2002). Natural infestation of onion seed by Pantoea ananatis, causal agent of center rot. Plant Dis 86, 106-111.

Wayne, L. G., Brenner, D. J., Colwell, R. R., Grimont, P. A. D., Kandler, O., Krichevsky, M. I., Moore, L. H., Moore, W. E. C., Murray, R. G. E. \& other authors (1987). International Committee on Systematic Bacteriology. Report of the ad hoc committee on reconciliation of approaches to bacterial systematics. Int J Syst Bacteriol 37, 463-464.

Weisburg, W. G., Barns, S. M., Pelletier, D. A. \& Lane, D. J. (1991). $16 \mathrm{~S}$ ribosomal DNA amplification for phylogenetic study. J Bacteriol 173, 697-703.

Wilson, K. (1987). Preparation of genomic DNA from bacteria. In Current Protocols in Molecular Biology, pp. 2.4.1-2.4.5. Edited by F. M. Ausubel, R. Brent, R. E. Kingston, D. D. Moore, J. G. Seidman, J. A. Smith \& K. Struhl. New York: Green Publishing \& Wiley-Interscience. 